give such prompt and real relief that the host of other remedies mny remain as an unemployed reserve. The physician summoned to a case of earache can gencrnlly leave his morphine and cocaine nt home, if he will take his brow-mirror, a syringe, and an ntomizer.

\title{
HYDROTHERAPY IN THE TREATMENT OF NERVOUS AND MENTAL DISEASES.
}

By Frederick Petersos, M.D.,

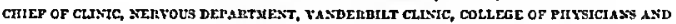

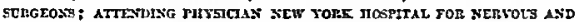

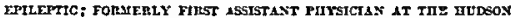
pRTER STATE HOSPTIAL FOR TIIF INSANE.

Ix advocating a more general use of hydrotherapy in diseases of the nervous system and in insanity, I wish to forestall criticism hy saying that I do not do so to the exclusion of other means of treatment, for wc possess adjuncts of grent importance in massage, Swedish gymnastics, passive and active machine movements, and dietetics, nll of which are nlso deserving of much wider attention than is usually given to them. It is too well known that the mere administration of drugs, very valuahle as many of tyom may he, and the employment of clectricity, even if done scientifically, as is seldom the case, are rarely sufficient in themselres, especially iu nervous diseases, to effect a cure.

Mnny of the scientific principles of hydrotherapy have already heen estahlished, but it would he well worth while to carry out at a few of our clinics and in the physiological lahoratories some of those elnhorate experiments with water which are frequently resorted to for the purpose of demonstrating the uses of new drugs. The "wnter treatment" certainly has mnny fentures which appeal strongly to our sense of rationnl treatment, for are we not nhle thereby to nffect very markedly the local innervation, to dilnte nnd contract vessels, alter the circulation in a part, chnnge the distrihution of the blood of the whole hody, retard or nocelerate the hlood-current, weaken or strengthen the cardiac contractions, rary the nmounts of secretion nnd excretion, increase beat radiation? And who can calculate to whnt degree we may thus infivence the hiochemical processes of the hody, the metaholism of tissues, the currying off of degenerated nnd toxic substnnces? or determine hov much we mny affect the vascular neuroses, the locnl nnæmias nnd hyperæmias of the hrain and spinal cord? We do wrong, therefore, not to properly investigate this agent, but to relegate hydrothernpy, as is so often the case in this country, to quncks who in some States are cven without n medical degree, yet who still are known to cure many cases that find their way into their hands. 
It would be well if some of our large schools would initiate a course of lectures on the suhject.

In continental Europe the "water cure" has hecome of late a scientific remedy, one recognized as of grent value, and everywhere-in asylums and hospitals, at health resorta, and in the cities-at the command of all physicians in private practice, are excellent means of making use of hydrotherapy where it is indicated.

I will here enter into details as to hydrotherapeutic measures only in so far as mental and nerrous disenses are concerned; their manifold applicntion in a great variety of general diseas:a, such as ferers, disorders of the stomach and intentinal tract, affections of the respiratory and circulatory organs, and the like, has hecome fairly well known in America, particularly through the earnest propaganda of Dr. Simon Baruch, of New York.

In my tour of inspection of asylums for the insane in Germany, Holland, France, Belgium, Italy, and Austria, in the winter of 1886-1887, I was surpriscd to find how universally hydrotherapy was employed in the trestment of certain conditions in insanity, and with what excellent results; and in a visit to the new insane asylum at Athens, Greece, in 1892, I was astonished to note how well equipped a hydrotherapeutic estahlishment it possessed, although situated in a country we are disposed to consider somewhat out of the track of modern progress.

On my return to America, in 1887, I put into practice, as well as means would permit, at the Hudson River State Hospital for the Insane, some of the principles of hydrotherapy that I had acquired ahroad, hut, as the facilities rere quite inadequate, my hydrotherapeutic measures wcre limited to applications of warm and cold baths, hrief or prolonged, the wet pack, wet compresses, and ice-hags. Nevertheless, I learned from ohservation and experimeut how much could be accomplished in the treatment of insomnia, congestive conditions, states of mental excitement, restlessness, and the like, hy even euch simple measures, and understood how much more might he done were each asylum provided with means for the methodical, syatematic, and scientific employment of the water treatment. As it is, I do not know of any asylum in America that is supplied with anything heyond the ordinary haths for purposes of cleanliness, and one of the ohjects of this article is to stimulate a more general consideration of the value of hydrotherapy hy asylum authorities, with the lope that it may lead to installations of the necessary apparatus in most of these institutions in our land.

With reference to general nervous diseases, I am sure there is a tendency every where among neurologists to look with more and more

1 Useg of Water in Modern Medieine. Detroit: Geo. S. Davis,

2 "Some Europesu Asylums," Am. Journ. of Insauity, April, 1887. 
complacency upon this means of treatmeat as one of great value. I kaow that this is true in all parts of Germany, Austria, nnd France. In some conversations with Professor Winteraitz, who, as is well knowa, occupies a speeial chair of hydrotherapy in the University of Vieana, I learned that ia his practiee of over thirty yesis' duratioa, fully threefourths of his patients were sufferers from nervous disorders, and his remarkable success in relieving nad curiag had cases is evcrywhere attested. I had the plensure of visiting his large estahlishment for hydrotherapy, at Knltealeutgehea, near Vienna, and of exnmiaing his methods and the apparatus he employs there.

I nm nware that amoag my neurological colleagues in New York, also, there is a growiag disposition to mnke greater use of hydrotberapeutic and mechanical treatmcut in nerrous diseases, though the facilities for properly carrying out some of the procedures are still to some extent wantiag.

\section{GENERAL LATH.}

The following are the ordiaary effects to be borae in miad in the applicatioa of hydrotherapy to disorders of the mind and nervous system :

1. Cold and wnrm haths affect the centrnl nervous system in a rcflex maaner by stimulatiag the sensory nerres of the skia and the rasomotor nerves, and thus iaflucaciag the cerebral circulation. Cold excites and warmth dimiaishes irritability when thus npplied.

2. Short cold baths, especially when combined with sprinkliag, sbowering, or rubbing, ure powerfully stimulating, exbilarating, aad tonic.

3. Proloaged warm baths, steam and hotair batbs, aad the hot pack, nre relaxing, fatiguiag, and soporific.

4. A cold bath stimulates vnrious reflexes in the hody, such as peristalsis and the viscernl reflexes in the sacral portion of the spianal cord.

5. Wnrm batbs, hy soothing peripheral acrve irritahility, exert a calmative iafueace orer the ceatrnl nervous system. They mitigate reflex spasm and coatractions ia voluntary or involuatary muscle.

6. Cold npplications to the shin stimulate vaso-dilntor aerves, dilate the peripberal vessels, nnd increasc blood-pressure. Wnrm applications also dilate superficial capillaries, hut hy dimiaishing the tone of the vessel walls they also reduce arterinl tension.

7. To lowcr the irritahility of individual nerves or of the eatire aervous system, prolonged warm haths or the hot pack are iadicated.

8. As maay hydrotherapeutic measures tend to rcduce temperature, it is importast to rememher that in non-fehrile cases, in ansmic conditions, and in dehilitated states, the tempernture must he mised artifi-

1 Since writing the above there has been established a Fydriatrie Institute at 035 Park A venue, with unusunl facilities. 
cinlly before suhjecting patients to hydriatric treatment. In some cases the temperature of the hody on rising from hed in the morning is sufficient; in others $\mathrm{n}$ short stay in the hot-hox mny he nceded.

\section{APPLIGATIONS IN CONDITIONB AMIONG TEE INBAXE.}

Before entering specifically into this subject, I wish to call the nttention of asylum plysicians to the ndaptahility of the rain-hath for the general purposes of cleanliness among pntients in their institutions.

The rnin-hnth was instituted in Vienna (ulthough the originator was $\mathrm{n}$ Berlin physician) in puhlic hnthing-houses for the purpose of increasing hathing fncilities, $i$. e., hy its use spnce could be economized, a greater numher of people could he cleansed in $n$ given time than hy ordinnry methods, ferrer servants were necessary, grenter cleanliness was attaiuahle, and the dnngers of contagion were minimized. This bath consists of a dressing-room for each person, a small room adjacent, where the hather can stand, and a gentle shower at low pressure, like rain, which descends upon him, washing him thoroughly from head to foot and flowing away at once upon impenetrahle floors into the sewers.

In our large asylunis, as is rell known, one or at nuost two stationary batb.tubs are supplied for eacb wnrd containing thirty to forty patients. There is a regular hathing-day each week, and upon that day most of the patients take baths in a way wbich is not nlways heyond criticism. They are hurried and imperfect baths, and frequently, if not carefully watched, the attendants make several patients hathe in the same water before cleansing the tub. The cleansing is not often as thorough as it should be. Besides the batbs given to all on regular bathing-dnys, the filthy pntients, that is, those who soil themselves in bed or who smear themselves with filth, are bathed frequently every day. While every precaution is taken as regards cleanliness that can he taken hy the asylum authorities, still one is iuclined to doubt the perfection of such bathing nrrangements, and it seems to me that the rain-bath system could he employed with even more advantage in these ingtitutions than in the puhlic baths of cities. I hope some of our progressive superintendents will initiate this chnnge. They will find in New York examples of the rnin-hnth system, recently introduced through the nhle advocaey of Dr. Baruch, at the public hnth-houses nt No. 7 Central Jarket Place, at the Demilt Dispensary (corner of Tirenty-third Street and Second Avenue), the Baron De. Hirseh Bnths, nt Essex nnd Market Streets, and at the Juvenile Asylum. Another ndvantage of the rainhnth in asylums would he the prevention of injuries such as oecur occasionally on putting excitahle patients into the tubs, nnd the impossihility of scalding or suicide. Rnre as these nccidents mny be, they hnve to he carefully guarded against under present nrrnngements. 
A simple hydriatric chamber. This might easily be provided in each ward-or, at lenst, in one out of five warde-by slight alteration of the present bath-rooms. The walls would require protection by means of a rubber lining, or, better, tiles or marble, and the floor should be zinc-lined, tiled, cemented, or made of asphalt. Several rain-haths should be installed. There should be one stationary hath tub. There should he several kinds of douches, connected with the hot and cold water pipes, and to this douche-apparatus should be attached a gauge for measuring the pressure. In aummcr the hydrant rater is never cool enough for some purposes, and a small reservoir should be arranged (coile packed in ice) for ohtsiniug cold water when required. A hot-air box is very useful. The equipment is complete when to these are added one or two foot-haths, a sitz-hath, Eeveral cooling-caps or ice-caps, Chapman's ice-hags, and a liberal aupply of linen for wet-packing, dry-packing, wet compresses, aad bandages.

It is very essential that such an establishment be put in charge of an intelligent nurse who would learn under the dircet instruction of the plysician ia charge bow to carry out properly every procedurc.

The room should be capahle of being hcated when in use to a temperature that will feel agreeable to the bather when uadressed. It is aeedless to say that patieats should aot he treated in a cold batll.room.

\section{IXDICATIONS' AND METHODS.}

For tonic and refreshing effects. A cold rain-bath $\left(\overline{0} 0^{\circ}\right.$ to $\left.70^{\circ}\right)$, the patient rubbiag himself while in the bath. Duration five to ten seconds; or the half-bath in a tub at $65^{\circ}$ to $75^{\circ} \mathrm{Fabr}$., tea to thirty miautes. By "half.hath" is meant oaly six to eight inches of water in the tub, in which the patieat lies and splashes ahout and is rubhed by an attendaat. The object in both is to get the exhilarating and stimulating cffects of the cold, and also the mechanical effect of the water impinging upon the skin. Such a bath should be taken every morniag.

For powerful tonic, revulsive, and derivative effects. The cold douche increases reflex excitability, and causes byperesthesia of the skin. It is a powerful atimulus, mental and physical. By means of various nozzles it may be ejectcd in the form of a jet, a spray, $\mathbf{n}$ shower, $\mathbf{n}$ fan, and by alternating with hot and cold water we have what is known as the Scotch douche. Such procedures nre indicated in lethlargic and hysterical forms of insanity, where there is sluggishness of the intellect, apathy, stupor, catalepsy, etc., and in melancholic cases, and in all cases where there is antemia, cblorosig, or gastric disorders.

To produce sleep. The prolonged war $m$ whole bath is indicated. Temperature $70^{\circ}-90^{\circ}$. Duration, one-balf to two hours. When of long duration the patient may be suspended in $n$ hammock made of a sheet. Indicated in cases of melancholia witb excitement and in some maniacal 
coaditions. As a geaeral hypnotic agent, bowever, applicable to all forms of insomnia among the ingane, the hot wet pack staads foremost. It is applied in this way: A blanket 9 hy 9 foct is spread upon the patient's bed, and upon this a sheet wrung out dry after dipping in hot water is laid. The patient lies down upon tbis, and the sheet is at once evenly arranged about and pressed around the whole hody with the exception of the head, after which the hlanket is also immediately likewise closely adjusted to every part of the patieat's hody. Other dry blankets may now be added as seems necessary. The patieat remains in this an hour or loager; all night if asleep.

Maniacal excitement. In this condition we all know how important it is to control motor excitement as much as possible in order to prevent the metaholic waste that progresses only too rupidly in many cases, often lending to denth from exhaustion in a few days. Formerly we were accustomed to fasten the patient in hed with a strait-jacket, and dose with hyoscyamine liberally, and this treatment uadoubtedly saved many lives, but the fasteaing in bed has beea to a great extent tabooed of late years. It is astonishing to note the good effects of hydrotberapy in many cases of this kiad. The measures to be carried out are those indicated for insomnia. It is not oftea tbat patients laboriag under great excitetueat can be placed in the warm bath, but the wet pack is applicable in nearly every case. It not only diminishes the crethism, but often brings about refresbiag sleep, and always when keptnpplied prereats metabolic waste hy motor excitement. I kaow of nothing that gives one better results in such cases tban the wet pack in conjunction witb overfeeding and occasional doses of hyoscyamine or duboisine if needed.

Congestive headaches. These headaches are quite common amoag the insane, and one of the best bydriatric procedures for their relief is a run. ning water cold foot bath every evening. The object is to dilate the vessels in the feet, to derive the blood from superior parts. One must, therefore, prescribe a prolonged foot-hath, accompanied hy ruhbiag aad chafiag of the feet for the mechanical effects of the water; or a strong fan douche of cold water applied to the feet very soon dilates the vessels and warms and reddens the feet. Actual experiment has shown that the temperature in the auditory meatus is lowered as much as one degree by a cold foot-bath, and conjuuctival vessels have heen observed to coatract.

Constipation. In the atonic condition of the intestines in most cases of melancholia and in some other forms of insanity, a powerful stiroulus to peristalsis will he found in pouring water over the ahdomen when the patient is in a tonic half-hatl of low temperature.

\section{APPLICATION OF HYDROTHERAPY IN NERVOUS DISEASES.}

The methods of using hydriatric measures for the purpose of a powerful nervine tonic and derivative, and to produce sleep and soothe nervous 
excitement and irritahility, lave heen described ahovc. I will add here some of the special indications in various ncrvous disorders in $n$ hrief and practical summary, alphahetically arranged.

Ancesthesia (cutaneous). Short cold jet and fan douches of strong pressurc to the ansesthetic areas. Temperature, $50^{\circ}$ to $70^{\circ}$. Duration one minute. Daily.

Angio-paralytic hyperidrosis of the feet. Prolonged cold foot-hath with chafing, or fan douche of cold water to the fect. Temperature, $60^{\circ}$. Duration twenty minutes for hath, five minutes for douche.

Chorea. Cold plunge heginning nt $90^{\circ}$, daily reducing until $70^{\circ}$ is reached.

If unæmic, spinal spray, jet or fon douches, nt first warm until patient hecomes accustomed to them, then gradually reduced to $60^{\circ}$ or $50^{\circ}$ (Dural).

Epilepsy. Cold shorrer haths and cold sponge haths daily are heneficial. The shower haths should he rain-like in character-that is, not too forcible.

In many cases a morning and evening hath (the "half-bath") proves rery servicenlle. The "half-bath" is taken in a bath-tub only half filled with water, and when taken should he accompanied hy energetic ruhhing of the patient hy an attendant. This bath lasts five minutes, and the temperature should not he under $50^{\circ}$ and not over $70^{\circ} \mathrm{F}$.

Where there is evidence of hypersemia and incrensed blood-pressure in the head, the cold cap is useful.

While these are the general indications for hydrotherapy, certain measures are often of use at the time of seizures. During a fit or during a status epilepticus it will he ohserred that there is one of two vascular conditions present: either the face is pale and there are signs of hrain anxemia, and in this case worm wet compreses should be applied to the head and genitals, accompanied by friction of the trunk upward, the hody heing placed with head low and arms uplifted; or there is turgescence of vessels in the head, the face is red, the carotids heat strongly, nod under snch conditions a contrary procedure is indicated-cold compresses to the head, neck, and genitals, strong wet heating of the feet, with a high position of the head. Daily applications for thirty seconds.

Headaches, neuralgias, and migraines. If anwmic, heating cephalic compresses (wring out thin linen handnges in very cold water; wrap hend in capelline manner, nnd cover with one or two lnyers of dry linen or flannel). Anply at hedtime. Upon removal, envelop head in dry cloth snd ruh it dry.

If hyperamic, leg bandages (a piece of towelling a yard long is dipped in cold water at one end-one-third-thoroughly wrung out and wrapped closely ahout each leg, so that the wet surface is nest the skin 
and the dry portion envelops the wet two or three times. Or, wet stockings mny be put on nnd covered witb dry towels). These nre applied at bedtime and retained through the night.

In many headaches, especinlly of a congestive character, a prolonged cold foot-batb (twenty minutes, $60^{\circ}$ ) or the fnn douche to the feet (five minutes, $60^{\circ}$ ) is very palliative.

Fysteria. Fur erethetic type: Wet pack, $60^{\circ}$ to $70^{\circ}$ for one hour or more, followed by massage (Putnam Jacobi); or the rnin-bntb at $75^{\circ}$ to $65^{\circ}$ for thirty-five seconds dnily at trenty pounds pressure (Bnrnch).

For depressed type: Cold affusions while standiag in warm water, or hot-nir bath, followed by rain-bath for thirty seconds nt $85^{\circ}$, daily reducing until $60^{\circ}$ is renched, this to be followed by sprny douche for five seconds at $65^{\circ}$, or jet douche for three seconds at $65^{\circ}$ to $55^{\circ}$. Reduce douche gradually to $50^{\circ}$ or less, increasiag pressure from tro pounds to thirty (Baruch).

Hypercesthesia (cutaaeous). Long-continued cold douches to affected ares. Daily tweaty miautes at $70^{\circ}$ to $80^{\circ}$.

Insomnia. Wet pack; see above.

Impotence. Brief cold sitz-baths. Daily, $56^{\circ}$ th $64^{\circ}$, oae to five minutes. The psycbropbore, $i$. e., application to prostate of cold by a rubber condom or bladder secured over a rectal irrigator an double conrant.

Incontinence of urine. In paresis of sphincter or detrusor brief cold sitz-batbs, daily, $56^{\circ}$ to $64^{\circ}$, one to five minutes. Cold raia-batbs ( $50^{\circ}$ to $\left.60^{\circ}\right)$ and douches as genernl tonics.

In spasmus detrusorum vesicx, on tbc coatrary, prolonged lukcwarm sitz-batbs, daily, thirty to sixty minuteg, $70^{\circ}$ to $90^{\circ}$.

Locomolor alaxia. Prolonged warm bnths, fivc to twenty minutes, $86^{\circ}$ to $95^{\circ}$ (Leyden). Hot-air baths to lower extremities followed by nffusions or douches, $60^{\circ}$ to $70^{\circ}$ (Hoeplein).

Neuralgia of all types, especially tic. Hot-nir batb, to perspirntion, every otber day, followed by gradually lowered doucbes (Barucb, Duval).

Sciatica. Hot-air hatb till pntient perspires, followed by cold plunge, or douche grndually lowered to $60^{\circ}$.

Spinal-cord affections. In various chronic disenses of the spinal cord tbe daily half-bnth, $65^{\circ}$ to $82^{\circ}$, six to ten minutes' durntion, with affusion and chafing, will be found useful. In some cases of compression nnd injury to the cord, in myelitis, nnd the like, where there is paralysis of the rectum and bladder and formntion of bedsores or trophic lesions, resort may bc had witb ndvantnge to the permnnent batb (Riess). A sheet fastened in a bath-tub makes a hnmmock in whicb tbe patient lies at first for $\mathrm{nn}$ hour or so dnily, Inter all the tine, except at night, when 
he is put to hed. The water is kept at a temperature agreeable to the patient $\left(88^{\circ}\right)$.

Spinal irritation. "Doucbe filiforme" as a rubefacient and epispastic along the spinal column; or rain-haths, $65^{\circ}$ to $85^{\circ}$, and douches.

Spermatorrhcea. Cold sitz-haths, five to twenty minutes, $50^{\circ}$ to $70^{\circ}$, daily at bedtime; contra-indicated in sexual irritahility and active pollutions, where prolonged warm or hot sitz-haths at $90^{\circ}$ to $98^{\circ}$ should be used.

Finally, I need scarcely any that if the alienist and neurologist are to make use of hydrotherapy at all, it must he borne in mind that precision of method is ahsolutely essentinl. As much care is necessary as in the preseription of drugs; for any violation of the principles or neglect of the modes determined hy long experiment and experience is certain to be followed hy unfortunate results.

201 West Fiftr-povata StaEst.

\section{MIETHODS AND RESULTS IN CASES OF NEOPLASMIS, VESICAL CALCULI, AND DISEASES OF THE BONES AND JOINTS.}

By J. WILliay WHite, MI.D.,

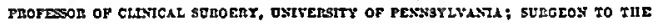
OSTVERSTTY AND GERMAY HOSPTTAIS, ETC.;

AxD

ALFRED C. WOOD, MI.D.,

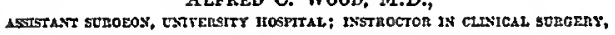

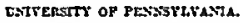

(Coulinted from pegu 68.)

MALIGXANT TUMORS OF THE BREAST.

Excisios of the hreast for carcinoma has been performed thirty-five times during the period embraced in this report." All of the cases recovered. Some of the patients were operated on while the cancers were still small; in most, the disease was well advanced. In performing the operation the usual elliptical incision was made, one extremity terminating in the axilln, and thus permitting of free access to this region. The hreast was incariahly entirely removed, and all affected skin sacrificed. The axillary glands were removed in every case, whether involved or not, principally hy the use of the finger. The wounds were usually drained for twenty-four hours, and witb few exceptions they healed hy

1 Sixteen enses have been operated upon by Dr. White at this writing (November 19th) since Octeber 1, 1892, but are too recent to include in this series. It may bo stated, bowever, tbat in all there was union by first intention. 